\title{
Islamic Financial Inclusion Contribution to The Empowerment and Development of Informal Sector
}

\author{
A. Nurasyiah, R. Rosida, N. S. Wulandari \\ Department of Islamic Economics and Finance \\ Universitas Pendidikan Indonesia \\ Bandung, INDONESIA \\ asnur.fna@upi.edu
}

\begin{abstract}
The background of this research is the issue of doubt or skepticism of the majority of the society's contribution towards the development of Islamic financial community, especially in the over-marginalized community including the informal sector entrepreneurs. Therefore, the aim of this research was to verify the contributions made by Baitul Maal Wat Tamwil (BMT) as an Islamic financial institution that is inclusive of the development of informal sector entrepreneurs. The method of research used descriptive qualitative and quantitative approach through different statistical tests. The samples are members of BMT Daarut Tauhid, BMT Baiturrahim and BMT Nurul Ummah. Thus, these samples are active members as part of informal sector entrepreneurs, who obtain financing and mentoring from the BMT. Based on a comparative research between the pre and post condition of members of BMT of informal sector entrepreneurs have increased the quality of life in terms of economy, social and spiritual. The results of implementation of the movement need to be more structured and massive in empowering society through the informal sector entrepreneurs through Islamic model of financial inclusion supported by government policy regulations which is proeconomic development for sustainable development.
\end{abstract}

Keywords: Islamic Financial Inclusion, Informal Sector and Empowerment

\section{INTRODUCTION}

Islamic banking as an Islamic financial institution which is more popular in the community have limitations in reaching the grass root of society because of the assumption that the financing for the informal sector (small traders) requires high cost and risk. In fact, the informal sector is a strategic sector that comes from self-reliance in entrepreneurship should be empowered to improve the welfare of the society or the poor economy. Baitul Maal Wat Tamwil (BMT) as an Islamic Financial Inclusion allows performing its role to empower informal sector entrepreneur where Islamic banks are not able to access efficiently.

BMT has empowered most of its members in which included into group of small and medium-sized community through financing and mentoring programs [1]. The research concludes that there is a difference between the average income of informal sector entrepreneurs that have access with those who have no access to formal financial institutions [2] [3] [4]. Thus, the informal sector must acquire a major concern to gain access to financial institutions which are sharia-based inclusive.
This paper attempts to explain how the BMT as an Islamic financial institution that is inclusive is able to play a role in social and economic life of its members who work as informal sector entrepreneurs. In contrast with the previous studies, the role of BMT in this case can be seen in particular to the informal sector entrepreneurs that are strategic community groups. In addition, the approach used wants to compare how changes in social and economic life before and after the informal sector entrepreneurs join the membership of BMT.

\section{LITERATURE REVIEW}

Islam emphasizes the Financial Inclusion explicitly distinguished the two characteristics, namely the concept of risk- sharing and redistribution of wealth. The impact of the concept of inclusive finance for development will differ significantly from the conventional financial industry (5). BMT offers products and services that are similar to Islamic banks and Islamic Rural Banks (BPRS).. However, it has a different market segment, since the Islamic banks serve mainly for the middle class and white-collar Muslims. Islamic Rural Banks or known as BPRS on the other hand, provides services primarily for the Muslims of the group of middle and lower income people. While BMTs usually serve Muslim customers who run small and medium enterprises and have access to Islamic banks are relatively limited.

Islamic approach to alleviate poverty as a major issue of development should ideally involve a comprehensive approach include (a) pro - poor programs, (b) achieve equitable distribution of income and (c) provide equal opportunities for all social segments (6). The most important constraints that poor people face to get out of poverty is due to the lack of access to credit to run their own business . Meanwhile it is the main requirement for them to take advantage of economic opportunities and escape from the poverty threat itself [7].

The effectiveness of BMT financing (as measured by paired sample t-test) in developing MEs has been evaluated by pointing out the change of business performance i.e. business income and profit by comparing the mean of these indicators at the first time the MEs joint BMTs (first condition) and when the research was conducted (second condition) [8].

Focuses the informal sector development on the assets, talents, and skill of individuals and channel them into small business ownership. The previous concepts indicate that informal sector development is not only enough by 
providing financial services, but also needs the wider range of other services (non-financial) which is useful for improving the effectiveness of financing (9). In other words, in terms of informal sector development (as a means of poverty alleviation), the availability a wider range of non-financial services to improve the effectiveness of financing is necessary.

The improving effectiveness of financing is not only useful for informal sector development and poverty alleviation, but also gives benefit to BMTs by reducing the risk of business and sustainability of the program. In Islamic perspective, for the perfection purpose of the previous concepts, the spiritual development especially via internalizing Islamic moral value in entrepreneur's consciousness (akhlaq) is also necessary. It is aimed to build up honesty, discipline, spirit, diligence, patience, piety, social responsibility, and arouse awareness, or to change the bad to good behavior. For the purpose of poverty alleviation, it is needed. Since, poverty not only is an economic issue, but also has moral, social and political dimensions [10].

\section{METHODOLOGY}

The research uses qualitative and quantitative approaches. A qualitative approach with descriptive statistics to illustrate how changes in social life perceived by informal sector entrepreneurs as members of BMT and their level of satisfaction with life. This descriptive research used a questionnaire employing an instrument that outline some of the statements to be answered by the respondents in response to the statement by the choice of using a Likert scale (very dissatisfied, dissatisfied, medium / neutral, satisfied and very satisfied.

In addition, to compare the difference in average income earned by informal sector entrepreneurs before and after joining the BMT, Paired $\mathrm{t}$ - test is also used. Data collected by distributing questionnaires and interviews to members of BMTs. The population used in this research is the informal sector entrepreneurs who receive financing from the BMTs in the city of Bandung and its surroundings. The sampling method used is purposive random as well snowball sampling. With these provisions, it is obtained that there were 72 active members BMT Daarut Tauhid BMT , BMT Baiturrahim, and BMT Nurul Ummah who work as informal sector entrepreneurs.

The hypotheses of this research are as follows:

$H_{0}: \mu_{D}=0$, It means that there are no differences in average income of informal sector entrepreneurs between before and after joining the BMT

$H_{0}: \mu_{D} \neq 0$, It means that there are differences in average income of informal sector entrepreneurs between before and after joining the BMT

The determination of the results of the hypothesis is to refuse $H_{0 y}$ if $t_{\text {stat }}>t_{\text {table }}$ and to receive $H_{0 \text { y }}$ if $t_{\text {stat }}<t_{\text {table }}$.

\section{FINDINGS AND DISCUSSION}

\section{A. Demography and Membership of BMT}

Based on descriptive studies to members of BMT is an informal sector entrepreneurs, can be described that in general the BMT members with members age between 31-
40 years old and have an education level of junior high school (SMP) in average. Related to BMT, most members joined in BMT since five years ago with the first loan amount range from IDR 1.000.000, - up to IDR 2.000.000,

As for the reason to join in the BMT, the members claimed that the requirements given by the BMT to obtain financing or loan is very easy. Therefore they feel attracted to join the BMT. In addition, the reason why they propose financing to BMT is generally to improve the business or existing business with the first loan amount average of IDR 500,000 , up to IDR 2.000.000,-. Most of them had already had a permanent business location for their shop or stall.

\section{B. The Role of BMT for Improving Socio-Economic Status Members}

BMT role contributes to the socio-economic status of members can be viewed using several indicators, namely changes in the level of average income of a member, the perception of socio-economic changes and a comparison between the present life condition with the earlier life one. Based on the results of field studies using questionnaires and interviews as an instrument, it can be observed that there are differences in average income of respondents as informal sector entrepreneurs between before and after joining the BMT. In more detail, this result can be seen in Table 1.

TABLE I. THE AVERAGE DIFFERENCE RESPONDENTS INCOME BEFORE AND AFTER JOIN THE BMT

\begin{tabular}{|c|c|c|c|c|c|}
\hline \multirow[t]{2}{*}{ No. } & \multirow[t]{2}{*}{ Income } & \multicolumn{2}{|c|}{ Before Join } & \multicolumn{2}{|c|}{ Afer Join } \\
\hline & & $\begin{array}{c}\text { Respon } \\
\text { dents }\end{array}$ & $(\%)$ & $\begin{array}{c}\text { Respon } \\
\text { dents }\end{array}$ & $(\%)$ \\
\hline 1. & $\leq 1.000 .000$ & 8 & 11.11 & 4 & 5.55 \\
\hline 2. & $\begin{array}{l}>1.000 .000 \\
\text { to } 2.000 .000\end{array}$ & 30 & 41.67 & 19 & $\begin{array}{c}26.3 \\
8\end{array}$ \\
\hline 3 & $\begin{array}{l}>2.000 .000 \\
\text { to } 3.000 .000\end{array}$ & 18 & 26.38 & 16 & $\begin{array}{c}22.2 \\
2\end{array}$ \\
\hline 4 & $\begin{array}{l}>3.000 .000 \\
\text { to } 5.000 .000\end{array}$ & 9 & 13.88 & 20 & $\begin{array}{c}27.7 \\
7\end{array}$ \\
\hline 5 & $\begin{array}{l}>5.000 .000 \\
\text { to } 8.000 .000\end{array}$ & 3 & 5.55 & 5 & 9.72 \\
\hline 6 & $>8.000 .000$ & 1 & 1.38 & 5 & 8.33 \\
\hline & Amount & 72 & $\begin{array}{c}100 \\
\%\end{array}$ & 72 & 100 \\
\hline
\end{tabular}

Source: The Results (Data Processed)

In addition, by using a statistical test Paired $\mathrm{t}$-test, it can be seen that the difference in average earnings before and after joining the BMT significantly different. These results can be seen from the results of SPSS output that with $\mathrm{N}=72 t_{\text {stat }}(7,23)$ and $t_{\text {table }}$ and with $\mathrm{df}=71$ is $1.666, t_{\text {stat }}>t_{\text {table }} \cdot(7,23>1,666)$, in addition to the significance value shows the value of 0.000 , meaning that the average income of respondents differed significantly.

The average income levels of the respondents are showing significant difference in relation with the situation between the prior and after their membership in the related BMT. These results proved that micro financing given by BMT giving positive energy and impacts towards the business development of its members.

In addition, respondents' perception of changes in socioeconomic conditions improved. By using a Likert 
scale with ranges of 1-5 and category 1 (very dissatisfied), for capital and their daily lives. Spiritual formation carried 2 (not satisfied), 3 (neutral /medium) , 4 (satisfied) to 5 out by BMT to its members is the main characteristic of (very satisfied). In general, respondents' perceptions of empowerment that may not done by many other financial changes in the socio-economic conditions can be observed institutions. in Table 2 .

TABLE II. SOCIO-ECONOMIC CONDOTIONS CHANGES IN THE PERCEPTION OF RESPONDENTS

\begin{tabular}{|c|c|c|c|}
\hline No & Indicator & $\begin{array}{c}\text { BEFORE } \\
\text { becoming a } \\
\text { member of } \\
\text { BMT }\end{array}$ & $\begin{array}{c}\text { AFTER } \\
\text { becoming a } \\
\text { member of } \\
\text { BMT }\end{array}$ \\
\hline 1 & $\begin{array}{ll}\text { Overall } & \text { Living } \\
\text { Conditions } & \\
\end{array}$ & Medium & Satisfied \\
\hline 2 & $\begin{array}{l}\begin{array}{l}\text { Adequacy of Food } \\
\text { /nutrition }\end{array} \\
\end{array}$ & Medium & Satisfied \\
\hline 3 & Adequacy Clothing & Medium & Satisfied \\
\hline 4 & State of Health & Satisfied & Satisfied \\
\hline 5 & State of Income & Medium & Satisfied \\
\hline 6 & State of Education & Satisfied & Satisfied \\
\hline 7 & $\begin{array}{l}\text { The Environmental } \\
\text { and safety situation }\end{array}$ & Satisfied & Satisfied \\
\hline 8 & $\begin{array}{l}\text { Peace of Mind and } \\
\text { Muslim Spiritual }\end{array}$ & Medium & Satisfied \\
\hline 9 & $\begin{array}{l}\text { The Level of Progress } \\
\text { of The Business }\end{array}$ & Medium & Satisfied \\
\hline 10 & $\begin{array}{ll}\text { The State of } \\
\text { Home/Residence }\end{array}$ & Satisfied & Satisfied \\
\hline
\end{tabular}

Source : The Results (Data Processed)

Before joining the BMT, the average of respondents do not obtain financing from other parties and some of them are also stuck with a loan shark loans. It is found that the benefit of the initial capital they received are in many cases interrupted and used for the household needs due to their inability to manage finances for the business well. Especially for those who are trapped with loanshark loans, business profits they earned are completely unable to be utilized. Even the initial capital was depleted to pay interest on the loan.. An economic indicator on average which has not changed is the state of the house or residence. This is caused by the short period of their membership with the BMTs i.e 5 years in average. On the other hand, the cost to renovate or buy a new home today is very costly, so they have not yet have the ability to repair or replace their residence to a more comfortable one.

In social aspects, such as education, health and safety, the perception of respondents remained unchanged in the category "satisfied" before and after becoming members of BMT. This is due to the availability of government program that cover the basic education and health care for the poor. With the nine -year free education program, targeting mission and Indonesian Social Security or known as BPJS suffice to help the society, so that the condition that the respondents had been satisfied before joining members of BMT. Similarly, the level of environmental safety they experienced is also constant.

Another interesting result is the perception of respondents who perceived that their spirituality have experienced improvement. Satisfaction levels were at first medium/ neutral turn into satisfied. Islamic environment atmosphere is attempted to be created by BMT, in hope that its members have the same spirit in increasing devotion to Allah SWT such as giving routine Islamic teaching activities arranged by the organization on regular basis . Peace of mind felt by respondents after joining the BMT also because they had not too much bothered by the need

Another conclusion of the respondent businesses of the informal sector is members of BMT who were respondents in this research experienced/ that their current living conditions compared to the five years earlier was no change $(6.94 \%)$, to be good $(69.44 \%)$ and became very good $(23.61 \%)$. These results prove how BMT has been an effective instrument in socio-economic life of its members, not only empowering economically, but also playing an important role in the improvement of social life members. These results are consistent with the previous studies that BMTs contribute to income, education and business enhancement, but the results show that the role of BMT not significant to the health improvement level (8).BMT financing is effective in reducing poverty. Most respondents can increase their revenue after receiving financing from the institution. BMT products mainly on mudharabah scheme have been able to empower the poor in various productive activities. BMT as an Islamic Financial Institution Inclusion has been instrumental in reducing financial bondage and poverty in the Muslim community(11)(10). These results are all in accordance with what is expected from BMT as a model of Islamic Financial Inclusion which plays an important role in improving economic conditions and other social factors of the members involved.

\section{CONCLUSION}

Based on the results of this research, it is concluded that the Baitul Maal Wat Tamwil (BMT) as a model of Islamic Financial Inclusion Institution has played an important role in the economy to members of informal sector entrepreneurs with an indicator of a significant change in income before and after joining the BMT. In addition, the descriptive research illustrated that on average they experienced a change in their socio-economic life to be better than before. This result is evidence that the financial inclusion model run by BMT may be a solution in empowering informal sector entrepreneurs to get out of poverty, as the major problem in development. These results can be improved by increasing the effectiveness of Islamic solidarity networking built between BMT and members involved (internal) and BMT with Islamic Bank, the government and other players in the industry (external). In addition, the necessary diversification of products, the provision of education and training for members, integrating social products such as Zakat, Infaq, Shodaqoh and Wakaf in providing financing to poor informal sector entrepreneurs are also needed.

\section{REFERENCES}

[1] Yuniar GN. Development of MSMEs ( Micro, Small and Medium Enterprises ) by Baitul Maal Wat Tamwil ( BMT ) as an Instrument for Poverty Reduction. 2015;3(2):41-4.

[2] Kumar N. Financial inclusion and its determinants: evidence from India. J Financ Econ Policy [Internet]. 2013;5:4-19. Available from:

http://www.emeraldinsight.com/10.1108/17576381311317754

[3] Khaki AR. Financial Inclusion in Karnataka : A Study on Banker' $s$ Initiatives. 2013;2(6):344-52.

[4] Bhanot D, Bapat V, Bera S. Studying financial inclusion in northeast India. Int J Bank Mark [Internet]. 2012;30(6):465-84. Available from: 
10.1108/02652321211262221 \nhttp://search.ebscohost.com/login.as px?direct=true \&db=bth\&AN=79723657\&site=ehost-live

[5] Mohieldin M, Iqbal Z, Rostom A, Fu X. The Role of Islamic Finance in Enhancing Financial Inclusion in Organization of Islamic Cooperation (OIC) Countries. Islam Econ Stud [Internet]. 2012;20(2):55-120. Available from: http://elibrary.worldbank.org/doi/pdf/10.1596/1813-9450-5920

[6] Hassan MK. an Integrated Poverty Alleviation Model Combining Zakat, Awqaf and Micro-Finance. Tawhidi Epistemol Zakat Waqf Econ. 2010;261-81.

[7] Ndlovu S. Journal of Sustainable Development in Africa (Volume 13, No.6, 2011). 2011;13(6):246-57.

[8] Bin Mislan Cokro Hadisumarto W, Ghafar B. Ismail A. Improving the effectiveness of Islamic micro-financing. Humanomics [Internet]. 2010;26(1):65-75. Available from: http://www.emeraldinsight.com/doi/abs/10.1108/082886610110250 02

[9] Ahmed H. Financing Microenterprises: An Analytical Study of Islamic Microfinance Institutions. Islam Econ Stud [Internet]. 2002;9(2):27-64. Available from: http://www.isdb.org/irj/go/km/docs/documents/IDBDevelopments/I nternet/English/IRTI/CM/downloads/IES_Articles/Vol 9-2..Habib Ahmed..Financing Microenterprises..dp.pdf

[10] Abdullah R. Al-Tawhidln in relation to the economic order of microfinance institutions. Humanomics [Internet]. 2014;30:325-48. Available from: http://www.emeraldinsight.com/doi/abs/10.1108/H01-2014-0006

[11] Abdul Samad M. Islamic micro finance: tool for economic stability and social change. Humanomics [Internet]. 2014;30(3):199-226. Available from: http://www.emeraldinsight.com/doi/abs/10.1108/H12-2013-0085 